\title{
THE SYNTHESIS AND CHARACTERIZATION OF IRON(II) GLUCONATE
}

Vesna D. Nikolić, Dušica P. Ilić*, Ljubiša B. Nikolić, Ljiljana P. Stanojević, Milorad D. Cakić, Ana D. Tačić, Snežana S. Ilić-Stojanović

Faculty of Technology, University of Niš, Leskovac, Serbia

(ORIGINAL SCIENTIFIC PAPER) UDC 661.872:615.273

This paper presents the synthesis and physico-chemical characterization of iron(II) gluconate as a potential antianemic drug for oral administration. Iron(II) gluconate was synthesized from sodium gluconate and iron(II) sulphate as precursors. The reaction product was purified by treating the crude reaction mixture with the acidic and basic ion exchange resins for the removal of $\mathrm{Na}^{+} \mathrm{i}$ $\mathrm{SO}_{4}{ }^{2-}$ ions. Iron(II) gluconate with the purity greater than $90 \%$ was obtained after evaporation in a vacuum evaporator, the treatment with aprotic solvent and drying in a desiccator over a dehydration agent. Molar ratio of 1:2 of iron and gluconate remains was determined by applying the Job's method. Structural properties of the obtained iron(II) gluconate were determined by using UV-VIS spectrophotometry, infrared spectroscopy (FT-IR), proton nuclear magnetic resonance $\left({ }^{1} \mathrm{H}-\mathrm{NMR}\right)$ and X-ray diffraction (XRD) methods. Thermal degradation of iron(II) gluconate was monitored by differential scanning calorimetry (DSC) and the results showed that synthetized and purified Iron(II)-gluconate was most probably in the form of dihydrate. The qualitative and quantitative analysis of iron(II) gluconate was performed by high performance liquid chromatography (HPLC).

\section{Introduction}

Modern understanding of the role of iron in the human body is very clear starting with how much of iron is needed for the normal function of the human body and what is its role in the metabolism, up to the consequences of iron's deficiency. Iron deficiency is a serious health problem, both in human and veterinary medicine. The amount of iron in the organism represents a balance between the inserted and resorbed amount on one hand and the eliminated amount on the other hand. A daily iron intake, its absorption and distribution in various organs and tissues compensates its loss and enables the maintenance of the constant iron concentration in the human organism [1]. Etiological factors that lead to disorders of iron balance in the body are: the inadequate intake of iron, a disorder of iron's absorption, the increased loss of iron in acute (injuries) and chronic cases (invisible bleeding from various tissues and organs) and the increased requirement for iron, especially in the period of growth, pregnancy, lactation, menopause, old age and convalescence [2]. All these conditions require the prevention or treatment by giving oral or parenteral iron-based preparations, depending on the type of anemia and its etiology. Oral therapy, as more suitable in medical practice, is applied only in terms of good iron absorption from the gastro-intestinal tract and, if no side effects such as nausea, pain or vomiting common for oral administration of iron preparations are present [3-5]. Iron(II) compounds have better absorption and they are mainly used in oral therapy [6]. However, almost without exception, all oral preparations, more or less, cause side effects. The pharmaceutical industry tends to different formulations of the final product (micro-encapsulation, polymer matrix, additives, etc.) to reduce side effects, but the currently achieved results have not been satisfactory $[7,8]$.

Iron(II) gluconate is a salt of the gluconic acid which represents a compound of iron and two molecules of gluconic acid. Iron(II) gluconate is a yellow-green crystalline powder, with the characteristic odor similar to burnt sugar [9]. In the crystalline state it is stable in the air, while its aqueous solution is sensitive to light. The solubility of iron(II) gluconate in water is $8.5 \mathrm{~g}$ in $100 \mathrm{~cm}^{3}$ of water at $20{ }^{\circ} \mathrm{C}$ [10]. It is poorly soluble in ethanol, and insoluble in ether. Iron(II) gluconate based preparations contain iron in the ferrous form, and their intake is recommended in the state of iron-deficiency anemia and bleeding. The iron compounds which are used in therapy can be classified into four main groups: iron salts, iron chelates, ferrocenes and polynuclear complexes of trivalent iron and carbohydrates [11]. Drynda and coleague investigated the effects of soluble bi- and tri-valent iron compounds 
on the expression of genes involved in the cholesterol synthesis and fatty acid metabolism in human smooth muscle cells [12].

Gluconic acid (2,3,4,5,6-pentahydroxyhexanoic acid) is a carboxylic acid formed by oxidation of the first carbon of glucose [13]. In aqueous solutions, gluconic acid forms the gluconate ion, $\mathrm{C}_{6} \mathrm{H}_{11} \mathrm{O}_{7}{ }^{-}$. The salts of the gluconic acid are known as gluconates. The chemical structure of gluconic acid consists of the six carbon chain with five hydroxyl groups and a terminal carboxyl group. Gluconic acid is not toxic to humans, so it is suitable for the production of iron(II)based preparations. The iron(II)gluconate based antianemic agents are therapeutically effective with a high tolerance $[14,15]$.

This investigation describes the method of synthesis and physicochemical characterization of iron(II)gluconate as a potential antianemic for oral administration. A classical method of synthesis starting from the sodium gluconate and iron(II)sulphate was applied. The resulting product and starting compounds for the synthesis were characterized using different methods. For the determination of the number of ligands that may be attached to the central iron ion, the Job's method was used. For the analysis, a series of isomolar solutions was prepared, with the molar ratio of metal and ligands varying from 0 to 1 , and the absorption being measured at $\lambda_{\max }$ for determination [16-19]. A HPLC method for the detection of synthesized iron(II) gluconate was developed.

\section{Experimental}

Substances and reagenses. Sodium gluconate $\left(\mathrm{C}_{6} \mathrm{H}_{11} \mathrm{NaO}_{7}\right)$, melting temperature $200-205{ }^{\circ} \mathrm{C}, \geq 99 \%$ purity (Aldrich, St. Louis, USA); iron(II) sulphate heptahydrate $\left(\mathrm{FeSO}_{4} \times{ }_{7} \mathrm{H}_{2} \mathrm{O}\right), 99,5 \%$ purity (Lachema, Neratovice, Chech Republic); sodium hydroxide (NaOH), $98 \%$ (Lachema, Neratovice, Chech Republic); hydrochloric acid $(\mathrm{HCl}), 3 \%$ (Lachema, Neratovice, Chech Republic); acidic resin Wofatit KP 4 (active groups: $-\mathrm{SO}_{3} \mathrm{Na}$ ) (VEB Chemiekombinat Bitterfeld, Germany); basic resin Amberlite IRA 416 (active groups: $\left.-\mathrm{N}+\left(\mathrm{CH}_{3}\right)_{3} \mathrm{Cl}^{-}\right)(\mathrm{VEB}$ Chemiekombinat Bitterfeld, Germany).

Ion exchange resin preparation.

The preparation of the basic ion exchange resin was done by treating the resin with $4 \% \mathrm{NaOH}$ solution and flushing with distilled water to $\mathrm{pH}=10$. The preparation of the acidic resin was performed by treating the resin with $6 \% \mathrm{HCl}$ solution and flushing with distilled water to $\mathrm{pH}=4$.

Synthesis of iron(II) gluconate.

Iron(II) gluconate was synthetised by the reaction of iron(II) sulphate and sodium gluconate in the molar ratio of $1: 2$. The sodium gluconate solution was heated at $70{ }^{\circ} \mathrm{C}$ and then the iron(II) sulphate solution was added with constant mixing. The reaction was performed at temperature of $90-100{ }^{\circ} \mathrm{C}$ during two hours with constant mixing. During this reaction, the solution colour changed from colourless to dark green. Sodium sulphate was also present in the reaction mixture as a secondary product, besides the iron(II) gluconate as the main product. The secondary product was removed from the reaction mixture using the appropriate resin. The reaction mixture was firstly treated by the acidic resin Wolfatit KP4 which removed $\mathrm{Na}^{+}$ions. Secondly, the basic resin which removes $\mathrm{SO}_{4}{ }^{2-}$ ions was used. This way, $\mathrm{Na}_{2} \mathrm{SO}_{4}$ as a secondary product was removed from the reaction mixture. After that, the iron(II) gluconate solution was dehydrated. The iron(II) gluconate solution was evaporated on the vacuum evaporator to minimal volume and then treated with the aprotic solvent, ethanol. The absolute ethanol was removed by decanting and the iron(II) gluconate was dried in a desiccator for several days. After drying, iron(II) gluconate was obtained in a form of dark green crystals.

\section{Characterization methods}

Job's method for determination of number of ligands.

In order to determinate number of ligands, the solutions of iron(II) sulphate $\left(1,39 \mathrm{~g} / 50 \mathrm{~cm}^{3} \mathrm{H}_{2} \mathrm{O}\right)$ and sodium gluconate $\left(1,907 \mathrm{~g} / 50 \mathrm{~cm}^{3} \mathrm{H}_{2} \mathrm{O}\right)$ were prepared. These solutions were used for the preparation of the reaction mixtures by mixing reactants in different volume ratios $(1: 9,2: 8,3: 7,4: 6,5: 5,6: 4,7: 3,8: 2$ and 9:1) and were used for synthesis, as described in the experimental part. After the reaction was finished, the absorbance of each mixture was measured.

Ultraviolet visible spectrophotometry (UV-VIS).

The UV-VIS spectra of iron(II) gluconate and sodium gluconate were recorded in the wavelength range of 190-600 $\mathrm{nm}$ on the Varian Cary 100 spectrophotometer. Distilled water was used as a blank.

Infrared spectrophotometry with Fourier transforms

(FT-IR).

FT-IR spectra of iron(II) gluconate and sodium gluconate were recorded by using a potassium bromide pellet technique in the wavenumber range of $4000-400 \mathrm{~cm}^{-1}$ on a Bomem Hartmann \& Braun MB-series FT-IR spectrophotometer. The spectrum of iron(II) gluconate was additionally recorded a couple of times in the liquid nitrogen stream at different low temperatures (from $-180{ }^{\circ} \mathrm{C}$ to $\left.0{ }^{\circ} \mathrm{C}\right)$.

\section{X-ray diffraction (XRD).}

Diffractograms of iron(II) gluconate and sodium gluconate were recorded on a Philips XPert powder diffractometer. The samples were exposed to monochromatic CuKa radiation and analyzed under the angle of $2 \theta$ between 5 and $65^{\circ}$ with $0.02^{\circ}$ increments and recording time, $t=5 \mathrm{~s}$. The voltage and strength of the electric current were $45 \mathrm{kV}$ and $40 \mathrm{~mA}$, respectively.

Nuclear magnetic resonance (NMR).

${ }^{1} \mathrm{H}-\mathrm{NMR}$ spectra of iron(II) gluconate and sodium gluconate were recorded in $\mathrm{D}_{2} \mathrm{O}$ on Bruker $\mathrm{AC} 250 \mathrm{E}$ with the working frequency of $250 \mathrm{MHz}$ in a glass cuvette of $5 \mathrm{~mm}$ diameter at room temperature.

Differential scanning calorimetry (DSC).

Thermograms were recorded on DuPont Instruments 
in the temperature range of $20-340{ }^{\circ} \mathrm{C}$ with the scanning rate of $10^{\circ} \mathrm{C} / \mathrm{min}$. The mass of the sample was $10 \mathrm{mg}$.

High performance liquid chromatography (HPLC).

The chromatograms were recorded on a HPLC Agilent 1100 Series chromatograph. The column was Zorbax Eclipse XDP-C18, $4.6 \times 150 \mathrm{~mm}, 5 \mu \mathrm{m}$. The eluent was a mixture of acetonitrile/water in the ratio $80 / 20, \mathrm{w} / \mathrm{w}$. The detection was performed by using UV detector at the wavelength of $205 \mathrm{~nm}$, at the temperature of $25^{\circ} \mathrm{C}$ and the injected volume was $20 \mu$ l.

\section{Results and Discussion}

Job's method for the determination of the number of ligands.

Dependency of absorbance on the mole fraction of metal or ligand has the characteristical maximum absorbance and indicates the complex formation. The projection of this point to apcise represents the molar ratio of metal-ligand in the complex. By using the Job's method, the optimal ratio of reactants in the synthesis of iron(II)gluconate can be determined. Figure 1 shows the Job's diagram that represents the dependency of absorbance change as a function of reactants molar ratio.

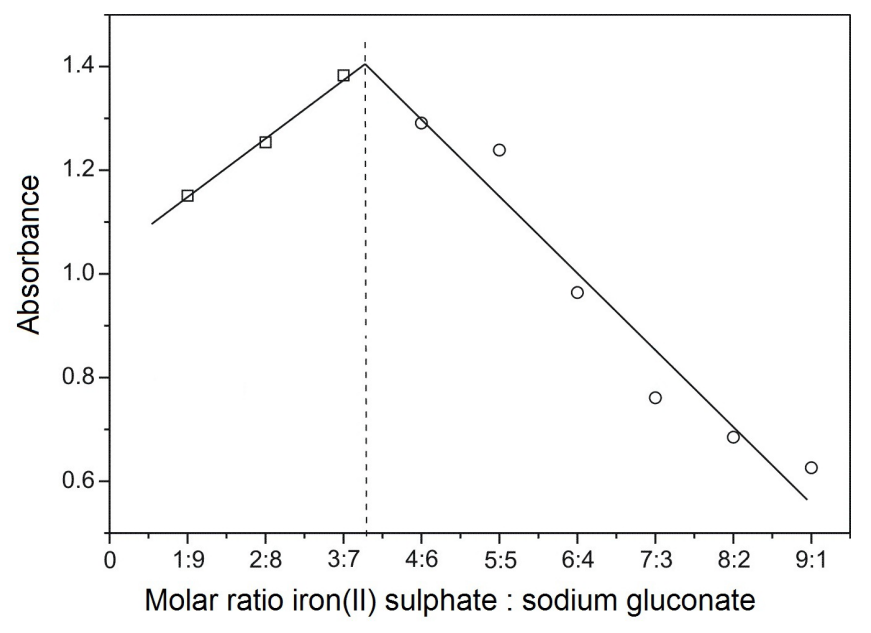

Figure 1. Determination of the molar ratio of iron(II) sulphate and sodium gluconate by the Job's method

From the Job's diagram it can be noticed that the maximum absorbance is reached with the molar ratio of iron(II)sulphate : sodium gluconate $(3.3: 6.7)$, which actually represents the ratio of $1: 2$. Based on this result, the synthesis of iron(II)gluconate can be represented by the following equation:

$$
2 \mathrm{Na} \mathrm{Glu}+\mathrm{FeSO}_{4} \rightarrow \mathrm{Fe} \mathrm{Glu} 2+\mathrm{Na}_{2} \mathrm{SO}_{4}
$$

Structural characterization of the iron(II)gluconate

For the structural characterization of iron(II)gluconate, UV-VIS, FT-IR, XRD i ${ }^{1} \mathrm{H}-\mathrm{NMR}$ methods were applied. UVVIS spectra of sodium gluconate and iron(II)gluconate

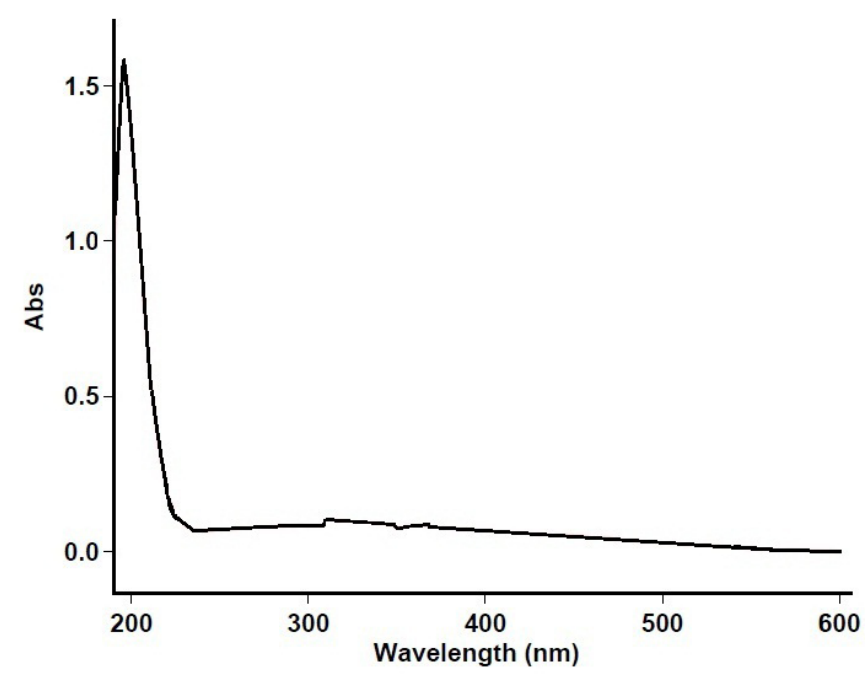

Figure 2. UV-VIS spectrum of sodium gluconate

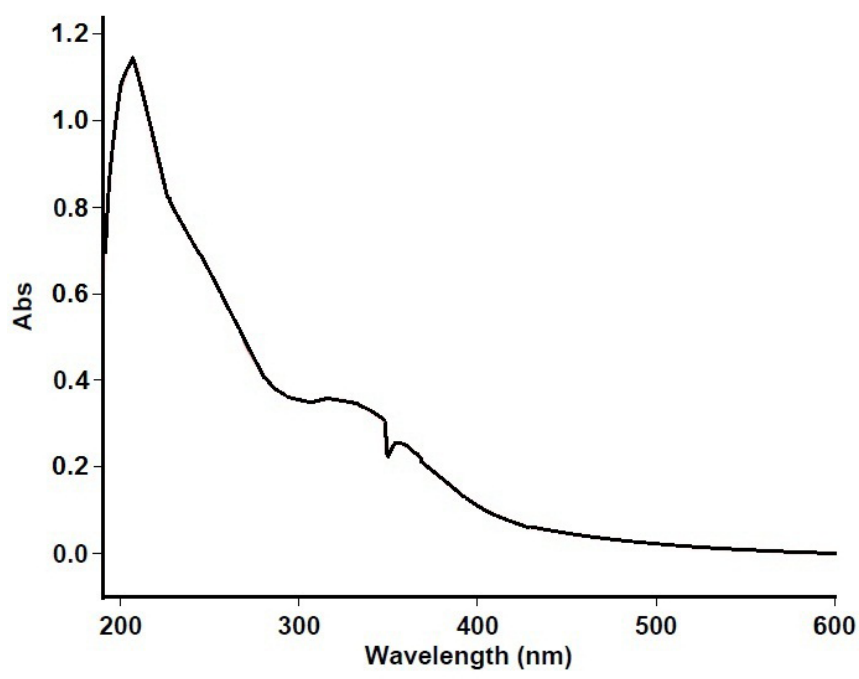

Figure 3. UV-VIS spectrum of iron(II) gluconate

UV spectra of sodium gluconate contains an absorption maximum at about $200 \mathrm{~nm}$, which represents a primary band and originates from $\pi \rightarrow \pi^{*}$ and $\Pi \rightarrow \sigma^{*}$ transition in the carboxylate anion of this molecule. UV spectra of iron(II)gluconate contains two absorption maximums, primary at about $200 \mathrm{~nm}$ and secondary at about $350 \mathrm{~nm}$, which are the results of resonance in carboxylate anions that reacted with iron(II) ion. The absorption maximum at $350 \mathrm{~nm}$ originates from $\mathrm{n} \rightarrow \pi^{*}$ transition in the carbonyl group of carboxylate anion as a result of delocalization of electrons within each of carboxylate ions that entered into interaction with the iron(II) ion.

Figure 4 shows the FT-IR spectrum of sodium gluconate.

From the FT-IR spectrum of sodium gluconate (Figure 4) it can be seen that the sodium gluconate structure contains several types of hydroxy groups, primary and secondary. The band of valence vibrations of primary $\mathrm{OH}$ group appears at $3541 \mathrm{~cm}^{-1}$, and the band of valence vibrations of secondary $\mathrm{OH}$ groups appears at $3430 \mathrm{~cm}^{-1}$. Deformation vibrations in the plane, $\delta(\mathrm{OH})$, appear as a 
complex band in the range of wavenumber from $1400 \mathrm{~cm}^{-1}$ to $1470 \mathrm{~cm}^{-1}$. The band of deformation vibration of $\mathrm{OH}$ group, $\mathrm{v}(\mathrm{OH})$, appears at $650 \mathrm{~cm}^{-1}$. The band of valence vibration, $\mathrm{v}(\mathrm{C}-\mathrm{O})$, of the primary alcohol group, appears at $1038 \mathrm{~cm}^{-1}$, and the band of valence vibration, $\mathrm{v}(\mathrm{C}-\mathrm{O})$, of the secondary alcohol group is also present in the spectrum of sodium gluconate and appears at $1095 \mathrm{~cm}^{-1}$. Very inten- sive bands at $1634 \mathrm{~cm}^{-1}$ and $1401 \mathrm{~cm}^{-1}$ in the spectrum of sodium gluconate are the results of valence asymmetric $\mathrm{v}_{\text {asym }}(\mathrm{C}=\mathrm{O})$ and symmetric vibrations $\mathrm{v}_{\text {sym }}(\mathrm{C}=\mathrm{O})$ of a carbonyl group of carboxylate anion.

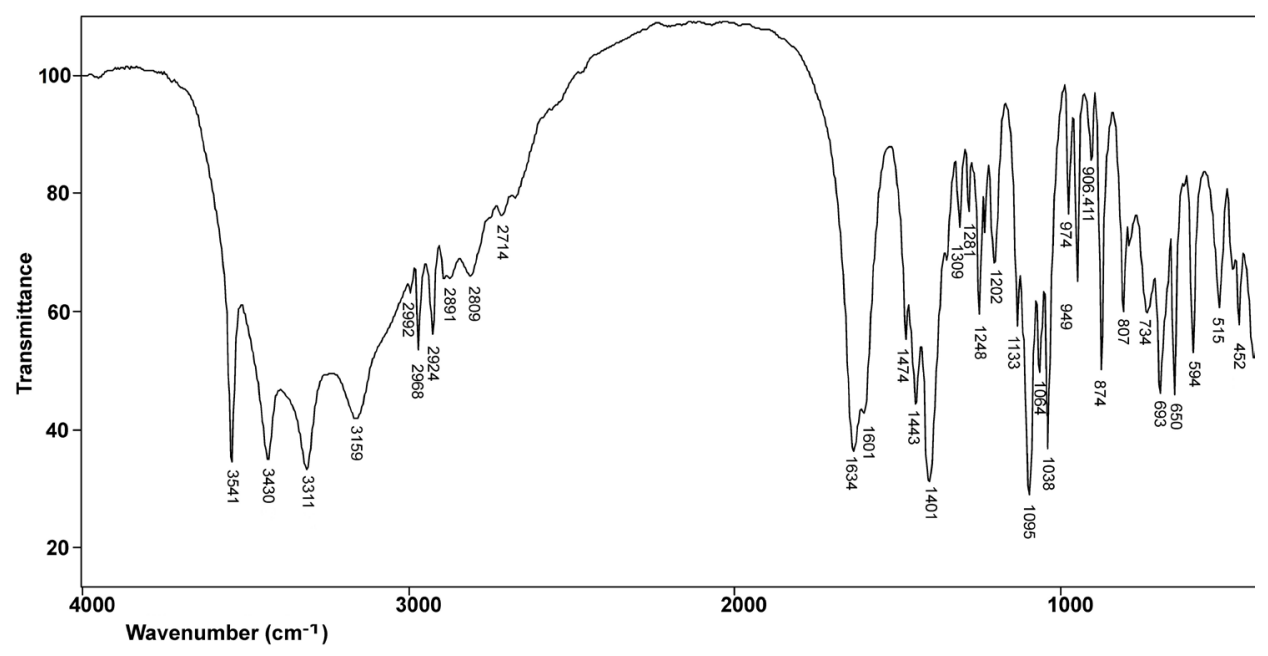

Figure 4. FT-IR spectrum of sodium gluconate

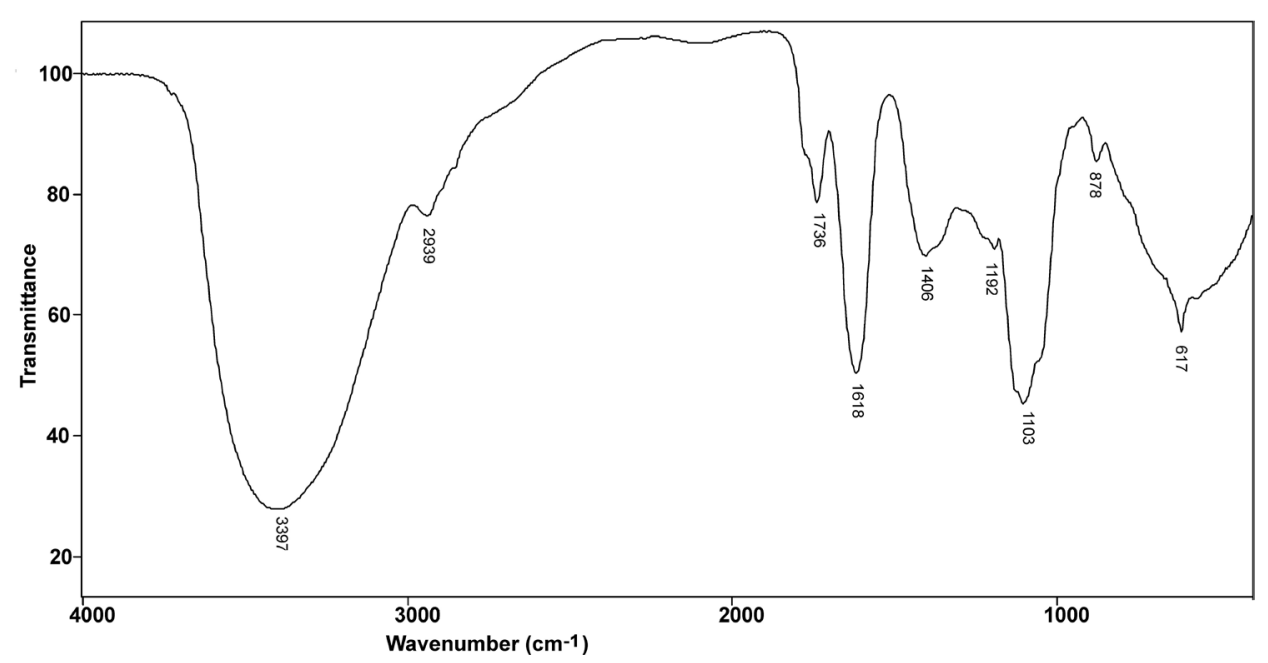

Figure 5. FT-IR spectrum of iron(II) gluconate

Figure 5 shows FT-IR spectrum of synthesized iron(II) gluconate.

By comparing the spectra of iron(II) gluconate and sodium gluconate it can be observed that the spectrum of iron(II)gluconate contains only one broad band of high intensity in the range from $3000 \mathrm{~cm}^{-1}$ to $3500 \mathrm{~cm}^{-1}$ with centroide at $3397 \mathrm{~cm}^{-1}$, which can be attributed to valence vibrations of hydroxyl groups, $v(\mathrm{OH})$, originating from the water present in iron(II)gluconate. The bands of valence vibrations of primary and secondary hydroxyl groups from the gluconate part of the molecule also appear in this area. They can not be observed in the spectrum of iron(II)gluconate because they are hidden by the intensive broad band of water. The bands of deformation vibrations of $\mathrm{OH}$ groups in the plane $\delta(\mathrm{OH})$ and out-ofplane $\mathrm{y}(\mathrm{OH})$ appear at $1400 \mathrm{~cm}^{-1}$ and $600 \mathrm{~cm}^{-1}$ which are shifted 5 units to higher and 33 units to lower wave numbers, respectively, as compared to the positions of these bands in the spectrum of sodium gluconate, which confirm the presence of primary and secondary hydroxy groups in the structure of iron(II)gluconate and the formation of non-covalent intramolecular hydrogen bond with the iron atom. In the FTIR spectrum of iron(II) gluconate two bands originate from valence vibrations 
of carboxylateanion $\mathrm{v}\left(\mathrm{COO}^{-}\right)$which interacts with the iron(II) ion. Asymmetric valence vibrations of carboxylate anions, $\mathrm{v}_{\mathrm{asym}}\left(\mathrm{COO}^{-}\right)$, appear at $1618 \mathrm{~cm}^{-1}$, and symmetric $\mathrm{v}_{\text {sym }}\left(\mathrm{COO}^{-}\right)$at $1406 \mathrm{~cm}^{-1}$ and they are shifted 16 units to lower and 5 units to higher wave numbers, respectively, as compared to the positions in the spectrum of sodium gluconate. These bands exhibit certain shift compared to the bands in the sodium gluconate spectra, which indicates a coordination of carboxylate group and iron(II) ion. More certain confirmation of the presence of water is provided by the spectrum of iron(II)gluconate previously deuterated with $\mathrm{D}_{2} \mathrm{O}$ and recorded in the stream of liquid nitrogen (Figure 6).

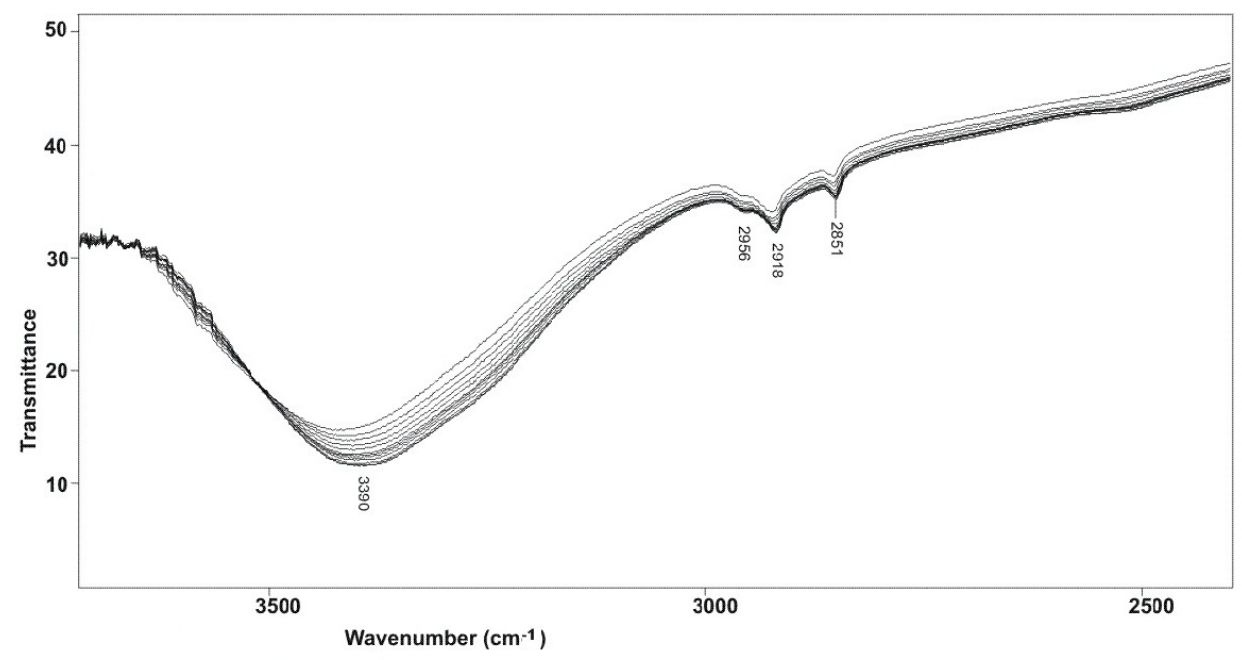

Figure 6. FT-IR spectrum of deutered iron(II) gluconate recorded in a stream of liquid nitrogen

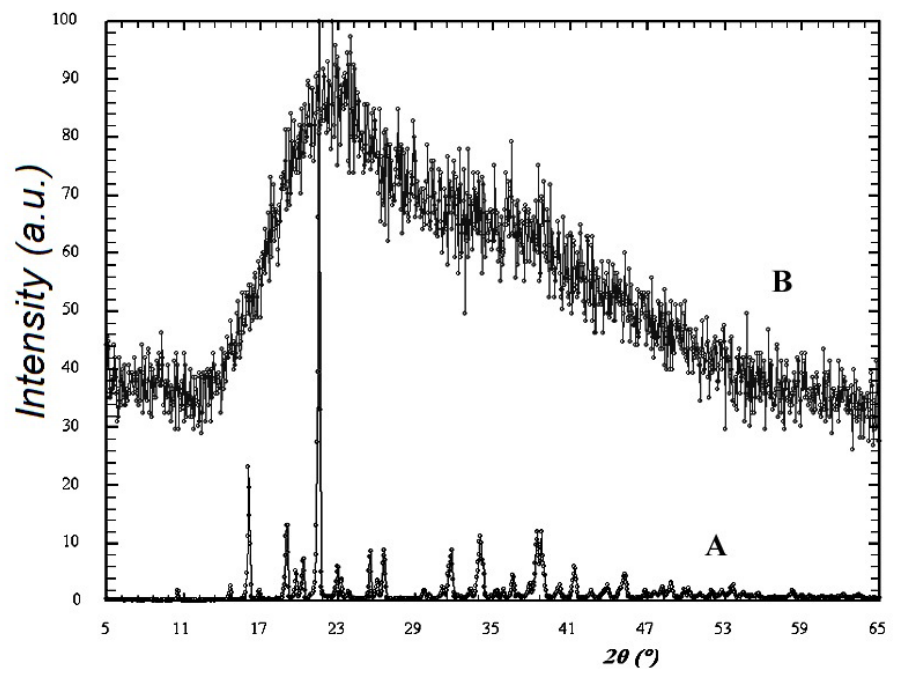

Figure 7. Diffractograms of sodium gluconate (A) and iron(II)gluconate (B)

Based on the analysis of FT-IR spectra, it can be concluded that the synthesized iron(II)gluconate represents a hydrate.

Figure 7 shows diffractograms of sodium gluconate and iron(II)gluconate.

By a comparative analysis of diffractograms it can be observed that sodium gluconate has a distinctive crystal structure which is confirmed by a large number of high intensity peaks at specific positions. The absence of pronounced peaks in the diffractogram of iron(II)gluconate indicates the amorphous nature of the synthesized iron(II) gluconate structure. This is confirmed by the presence of wide peaks with approximately uniform intensity, which is a characteristic of an amorphous structure.

The ${ }^{1} \mathrm{H}-\mathrm{NMR}$ spectra of sodium gluconate and iron(II) gluconate are shown in Figures 8 and 9, respectively. 


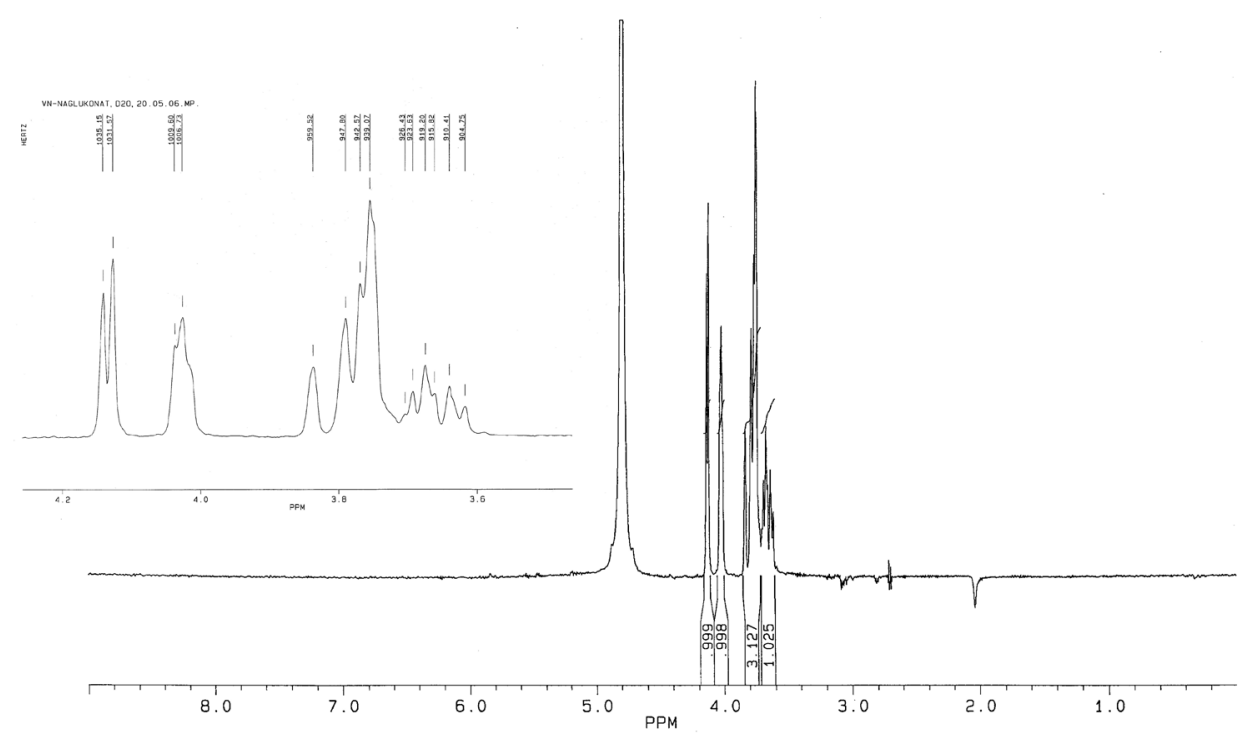

Figure 8. ${ }^{1} \mathrm{H}-\mathrm{NMR}$ spectrum of sodium gluconate

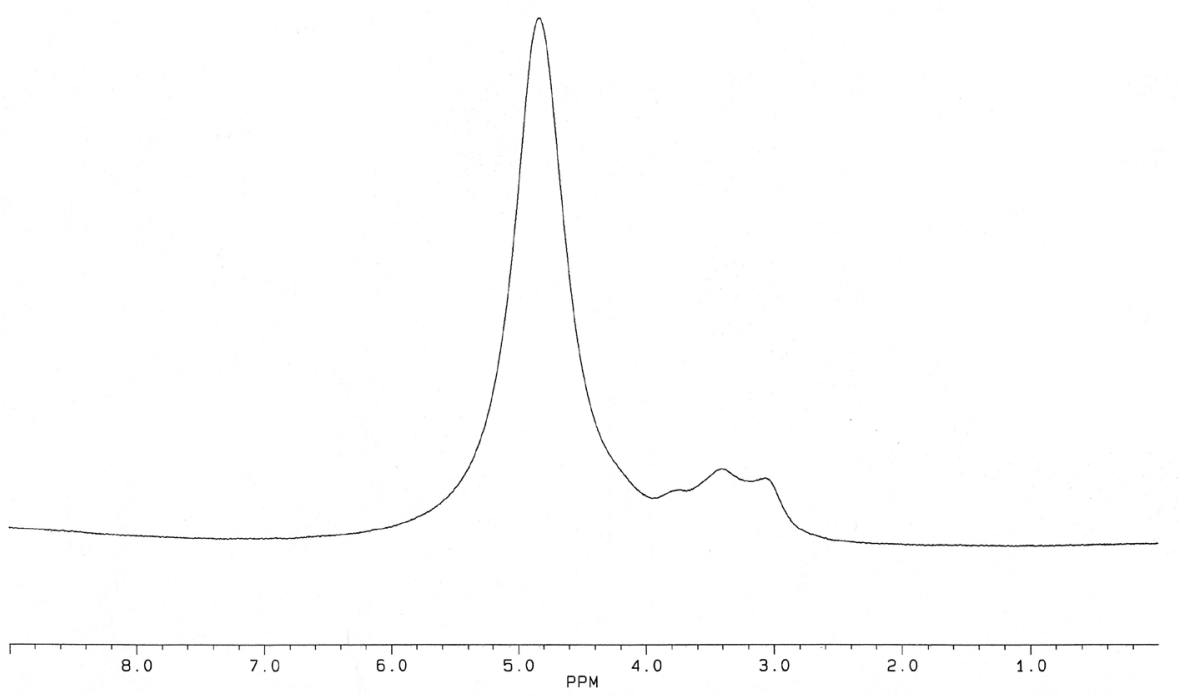

Figure 9. ${ }^{1} \mathrm{H}-\mathrm{NMR}$ spectrum of iron(II)gluconate

The structures of both molecules contain a large number of $\mathrm{OH}$ groups for which hydroxyl protons have no signal in the ${ }^{1} \mathrm{H}-\mathrm{NMR}$ spectra, because these protons are replaced by deuterium from deuterated water which is used as a solvent for spectra recording. The coupling of the hydroxyl protons with the protons on the adjacent carbon atoms was not achieved due to rapid exchanges of hydroxyl protons. The signal at $\delta 4.8 \mathrm{ppm}$ present in both of spectra, especially expressed in the spectrum of iron(II) gluconate, was derived from the partially deuterated water molecule (HOD). The partially deuterated water molecule is formed by changing the hydroxyl proton of the carboxylate group with deuterium atom from $\mathrm{D}_{2} \mathrm{O}$, and by changing the hydroxyl proton of the water molecule with deuterium atom, which is an integral part of the iron(II)gluconate structure. Low intensity multiplet without clearly resolved peaks in the range of $\delta 3-4 \mathrm{ppm}$ is generated by the coupling of protons present in the $\mathrm{C}-\mathrm{C}$ structure of iron(II)gluconate. The signals of the coupled protons in the spectrum of sodium gluconate occur in the range of $\delta 3.6-4.2 \mathrm{ppm}$. In the part of the molecule NaOOC-CH-CH, a dublet at $\delta 4.125 \mathrm{ppm}$ is formed by coupling marked protons in the structure. A dublet at $\delta$ $4.05 \mathrm{ppm}$ is a result of protons coupling of $\mathrm{CH}_{2}$ group and adjacent $\mathrm{CH}$ protons. A multiplet in the area of 3.6-3.85 is formed by mutual coupling of $\mathrm{CH}$ protons and surrounding protons of the $\mathrm{CH}$ and $\mathrm{CH}_{2}$ groups of sodium gluconate. Thus obtained spectra and their analysis are in compli- 
ance with the testing by FT-IR and DSC methods and indicate that the iron(II) gluconate hydrate is synthesized.

The results of DSC analysis of sodium gluconate, as a starting compound, and iron(II)gluconate, as a product of synthesis, are shown in Figure 10.

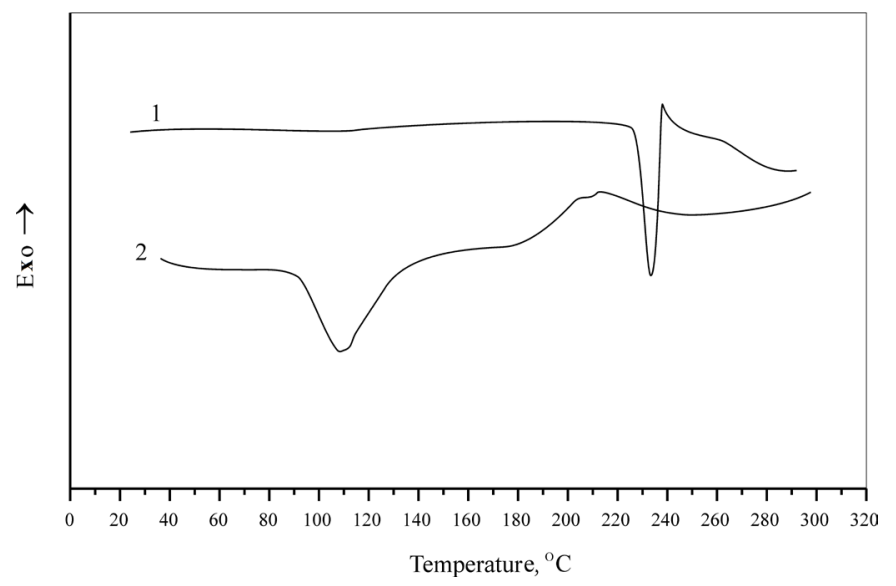

Figure 10. The thermogram of sodium gluconate (1) and iron(II)gluconate (2)

The destruction mode of sodium gluconate (Figure 10 , thermogram 1) shows a single endothermic peak in the narrow temperature range of $225-238^{\circ} \mathrm{C}$ which indicates that a starting compound is very pure. The top of this peak at $234{ }^{\circ} \mathrm{C}$ actually represents the melting point of sodium gluconate. The thermogram of sodium gluconate does not indicate any significant changes of the structure up to $300{ }^{\circ} \mathrm{C}$.

The thermogram of iron(II)gluconate (Figure 10, thermogram 2) has no endothermic peak at $234{ }^{\circ} \mathrm{C}$, which means that the synthesized product does not con- tain the starting compound, i.e. the reaction of the synthesis is completely achieved at given reaction conditions. It is well known that iron(II)gluconate exists as monohydrate and dihydrate. The melting point of iron(II)gluconate dihydrate is $188^{\circ} \mathrm{C}$, while the melting point of iron(II) gluconate monohydrate is not found in the available literature. In the published data, iron(II)gluconate dihydrate $\left(\mathrm{Fe}\left(\mathrm{C}_{6} \mathrm{H}_{11} \mathrm{O}_{7} \cdot \mathrm{H}_{2} \mathrm{O}\right)_{2} \rightarrow \mathrm{FeO}_{3 / 2}\right)$ shows one endothermic peak at $123{ }^{\circ} \mathrm{C}$ due to the dehydration and two exothermic peaks, the first at $210{ }^{\circ} \mathrm{C}$ (from the decom-position of iron(II)gluconate anion) and the second at $319^{\circ} \mathrm{C}$ [20]. A wide endothermic peak at about $108{ }^{\circ} \mathrm{C}$ points to the dehydration of $\mathrm{FeC}_{12} \mathrm{H}_{22} \mathrm{O}_{14} \cdot 2 \mathrm{H}_{2} \mathrm{O}$. The oxidative decomposition of the complex $\mathrm{FeC}_{12} \mathrm{H}_{22} \mathrm{O}_{14}$ indicated the presence of four exothermic peaks at $220,293,350$ and $421^{\circ} \mathrm{C}$ [21]. In the thermogram of the synthesized iron(II)gluconate (Figure 10, thermogram 2) the presence of a broad endothermal peak due to dehydration in the temperature range of $95-125^{\circ} \mathrm{C}$ with a maximum at $108^{\circ} \mathrm{C}$ indicated the loss of two water molecules, which is in agreement with the literature data $[20,21]$. In the thermogram of the synthesized iron(II)gluconate a shoulder existed at $188^{\circ} \mathrm{C}$, which is also in agreement with the literature data [20] and suggested the presence of dihydrate. In the area of $215-213^{\circ} \mathrm{C}$ (Figure 10, ther-mogram 2) there was an exothermic peak of low intensity at $212{ }^{\circ} \mathrm{C}$ which can, according to the data published in the literature, indicate the oxidative decomposition of iron(II)gluconate [21]. Based on DSC analysis, it can be concluded that the synthesized and purified iron(II)gluconate is most probably in the form of dihydrate.

HPLC chromatogram of iron(II)gluconate is shown in Figure 11.

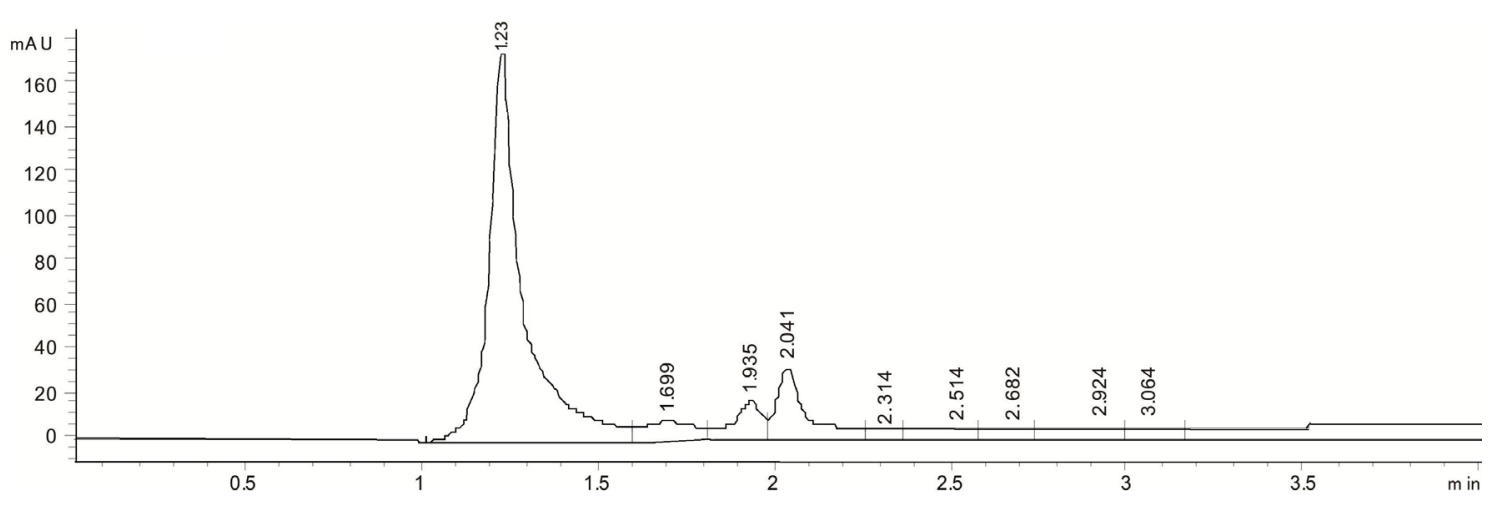

Figure 11. HPLC chromatogram of the synthesized the iron(II) gluconate

HPLC chromatogram shows that the retention time of the synthesized iron(II)gluconate is $1.23 \mathrm{~min}$. Also, it can be concluded that the synthesized iron(II)gluconate has a high purity (>92\%) because the chromatogram impurity peaks have a very low intensity and are present in about $8 \%$ of the total content of the analysed sample. On the other hand, this means that the reaction of the synthesis is selective and has a high degree of conversion. Retention time of iron(II)gluconate for the proposed HPLC method shows the deviation from the value of $1.23 \mathrm{~min}$ of no more than $0.01 \%$, after repeated testing of the sample, which indicates the high reproducibility of this method. The injection of the same volume and the concentration of the samples shows no significant 
changes in the peak area of iron(II)gluconate, which indicates acceptable accuracy of quantitative determination of iron(II)gluconate. The assumed structure of iron(II) gluconate based on the analysis is shown in Figure 12.

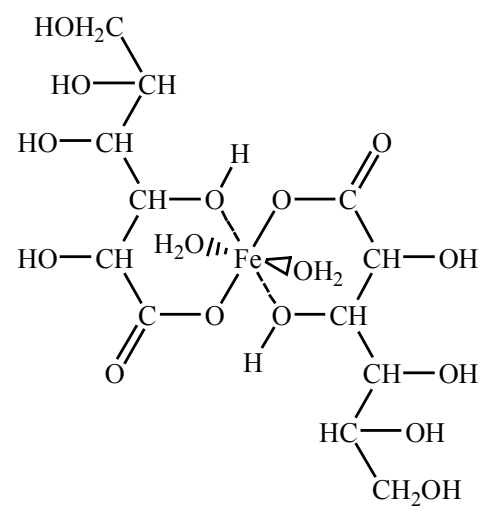

Figure 12. The estimated structure of iron(II) gluconate

\section{Conclusion}

Iron(II)gluconate as oral antianemic was synthesized by the conventional synthesis process and by using sodium gluconate and iron(II)sulphate as precursors. A crude product was purified by applying acidic and basic ion exchange resins (for removal of $\mathrm{Na}^{+}$i $\mathrm{SO}_{4}{ }^{2-}$ ions), treated with the aprotic solvent (ethanol) and dried. As a result, iron(II) gluconate of great purity (over 90\%) was obtained. Molar ratio of iron(II) sulphate:sodium gluconate of 1:2 was obtained by applying the Job's method. The obtained iron(II) gluconate was dihydrate with an amorphous structure, which was proved by using UV-VIS, FT-IR, XRD and ${ }^{1} \mathrm{H}-\mathrm{NMR}$ methods. The presence of endothermic peak on DSC thermograms which are in accordance with literature data indicates the existence of water as a dihydrate bonded to the iron(II)gluconate molecule. The retention time for iron(II)gluconate in the HPLC chromatograms is $R_{t}=1.23$ min.

\section{Acknowledgements}

This work is a part of the research done within the project TR 34012. The authors would like to thank the Ministry of Education, Science and Technological Developments of the Republic of Serbia.

\section{References}

[1] M. Cakić, G. Nikolić, D. Cvetković, Lj. Ilić, Kompleksi $\mathrm{Fe}(\mathrm{III})$ sa oligosaharidima, Antianemici, Monografija, Tehnološki fakultet, Leskovac, Unuverzitet u Nišu, 2007.

[2] S. Stefanović, Anemije malokrvnosti, Medicinska knjiga, II izdanje, Beograd-Zagrab, 1990.

[3] D. M. Cvetković, V. D. Nikolić, Lj. B. Nikolić, Ispitivanje primarnih fizičko-hemijskih i farmako-bioloških karakteristika polinuklearnih kompleksa gvožđa(III) sa dekstranom i njegovim derivatima, Chemical Industry \& Chemical Engineering Quarterly, 11(1) (2005) 30 - 35.
[4] M. I. Oshtrakh, O. B. Milder, V.A. Semionkin, Determination of the iron state in ferrous iron containing vitamins and dietary supplements: Application of Mössbauer spectroscopy, Journal of Pharmaceutical and Biomedical Analysis, 40 (2006) 1281 - 1287.

[5] L. Hallberg, H. G. Harwerth, A. Vannotti, Iron deficiency, Academic press, London and New York, 1970, p. 537 550.

[6] H. M. Schmitz, Vergleichende Untersuchung über die therapeutische Wirkung oral applizierter Eisen (II)- bzw. Eisen (III)-Antianämica, Arzneimittel-Forschung, 21 (1971) 509 - 515.

[7] L. L. Diosady, J. O. Alberti, M. G. Venkatesh Mannar Microencapsulation for iodine stability in salt fortified with ferrous fumarate and potassium iodide, International Journal of Food, 35 (2002) 635 - 642.

[8] N. G -C. Maria, Carotenoids increase iron absorption from cereal-based food in the human, Nutrition Research, 26(7) (2006) 340 - 34.

[9] USP 30-NF 25. United States Pharmacopeia 30 The National Formulary 25. (2007) United States Pharmacopeial Convention, Rockville, MD.

[10] http://www.jostchemical.com/MSDS/Fe $\% 20$ GLUCONATE\%20MSDS\%20DE.pdf

[11] A. J. Kapor, Lj. B. Nikolić, V. D. Nikolić, M. Z. Stanković, M. D. Cakić, D. P. Ilić, I. I. Mladenović-Ranisavljević, I. S. Ristić, The synthesis and characterization of iron(II) fumarate and its inclusion complexes with cyclodextrins, Advanced technologies, 1 (1) (2012), 07-15

[12] A. Drynda, R. Hoehn, M. Peuster, Influence of Fe(II) and $\mathrm{Fe}(\mathrm{III})$ on the expression of genes related to cholesteroland fatty acid metabolism in human vascular smooth muscle cells, Journal of Materials Science: Materials in Medicine, 21 (2010) 1655 - 1663.

[13] S. Ramachandran, P. Fontanille, A. Pandey, C. Larroche, Gluconic Acid: Properties, Applications and Microbial Production, Food Technology and Biotechnology, 44 (2) (2006) 185 - 195.

[14] M. Molliard, Production d’acide citrique par le Sterigmatocystis nigra, Comptes Rendus, 174 (1992) 881 $-887$.

[15] S. A. Waksman, J. W. Foster, Respiration and lactic acid production by a fungus of the genus rhizopus, Journal of Agricultural Research, 57 (12) (1938) 873 - 899.

[16] P. Job, Annali di Chimica Applicata, 9, (1928) 113 - 203.

[17] J. S. Coleman, L. P. Varga, S. H. Mastin, Graphical methods for determining the number of species in solution from spectrophotometric data, Inorganic Chemistry, 9 (5), (1970) 1015 - 1020.

[18] Z. D. Hill, P. MacCarthy, Novel Approach to Job's Method, Journal of Chemical Education, 63 (3) (1986) 162 - 167.

[19] S. B. Tošić, Proučavanje sistema: mono i disulfonovani produkti hidrohinona-joni metala, Doktorska disertacija, Univerzitet u Nišu, Prirodno-matematički fakultet, odsek za hemiju, 2009.

[20] Z. Gabelica, A. Charmot, R. Vataj, R. Soulimane, J. Barrault, S. Valange, Thermal degradation of iron chelate complexes adsorbed on mesoporous silica and alumina, Journal of Thermal Analysis and Calorimetry, 95 (2) (2009) 445 - 454.

[21] M. M. Rahman, A. Venkataraman, Synthesis of $-\mathrm{Fe}_{2} \mathrm{O}_{3}$ by thermal decomposition of ferrous gluconate dihydrate, Journal of Thermal Analysis and Calorimetry, 68 (2002) $91-101$. 
Izvod

\section{SINTEZA I KARAKTERIZACIJA GVOŽĐE(II)-GLUKONATA}

Vesna D. Nikolić, Dušica P. Ilić, Ljubiša B. Nikolić, Ljiljana P. Stanojević, Milorad D. Cakić, Ana D. Tačić, Snežana S. Ilić-Stojanović

U radu su prikazani rezultati sinteze i fizičko-hemijske karakterizacije gvožđe(II) glukonata kao potencijalnog antianemika za oralnu primenu. Gvožđe(II)glukonat je sintetisan konvencionalnim postupkom sinteze polazeći od natrijum glukonata i gvožđe(II)sulfata kao prekursora. Reakcioni proizvod je prečišćen tretiranjem sirove reakcione smeše kiselom i baznom jonoizmenjivačkom smolom za uklanjanje $\mathrm{Na}^{+}$i $\mathrm{SO}_{4}{ }^{2-}$ jona. Nakon uparavanja na vakuum uparivaču, tretiranja aprotičnim rastvaračem i sušenja u eksikatoru iznad dehidratacionog sredstva, dobijen je gvožđe(II)glukonat čistoće oko 90\%. Primenom Jobove metode utvrđen je molski odnos gvožđa i glukonatnih ostataka 1:2. Strukturne karakteristike dobijenog gvožđe(II)glukonata ispitane su primenom metoda ultraljubičaste spektrofotometrije (UV-VIS), infracrvene spektroskopije (FT-IR), protonske nuklearne magnetne rezonance $\left({ }^{1} \mathrm{H}-\mathrm{NMR}\right)$ i difrakcije rendgenskih zraka (XRD). Termalna degradacija gvožđe(II)glukonata praćena je metodom diferencijalne skenirajuće kalorimetrije (DSC) i rezultati ukazuju da je sintetisan i prečišćen gvožđe(II)glukonat najverovatnije u obliku dihidrata. Tečnom hromatografijom pod visokim pritiskom (HPLC) izvršeno je kvalitativno i kvantitativno određivanje gvožđe(II)glukonata.
Ključne reči: gvožđe(II)-glukonat, sinteza, antianemici 